\title{
Green Manure Intercropped with Okra for Spontaneous Plant Suppression
}

\author{
Raimundo Nonato Viana Santos, Luciana Lins Oliveira Santos, Caio Vinícius Sales Pereira \\ da Macena \\ State University of Maranhão, Brazil
}

Denise Lima Cavalcante Marinho

State University of Tocantina Region of Maranhão

\begin{abstract}
Maria José Pinheiro Corrêa, Mario Luiz Ribeiro Mesquita, Maria Rosangela Malheiros Silva State University of Maranhão, Brazil
\end{abstract}

Received: Sep. 3, 2020

Accepted: Oct. 9, 2020

Published: Oct. 15, 2020

doi:10.5296/jas.v8i4.17625

URL: https://doi.org/10.5296/jas.v8i4.17625

\begin{abstract}
Spontaneous plants are biological factors that compromise the yield of vegetables. The hypothesis is that green manure intercropped with okra suppress spontaneous plants and increase the production of this vegetable. The research aimed to evaluate the viability of green manure intercropped with okra to suppress spontaneous plants and increase vegetable productivity. The design was in randomized blocks with four replications and 10 treatments: cowpea [Vigna unguiculata (L). Walp.], sunn hemp (Crotalaria juncea L.), velvet bean [Mucuna nivea (L.) DC.] and dwarf pigeon pea [Cajanus cajan (L.) Huth] intercropping and monoculture with two controls without green manure. The green manure reduced the dry mass of spontaneous plants but did not increase the production of okra. The average values of the equivalent area index (EAI) in all intercropping were higher than one. Green manure is efficient in suppressing spontaneous plants, but to increase the productivity of the okra, adjustments must be made in the green manure-okra intercropping.
\end{abstract}

Keywords: Abelmoschus esculentus L. Moench, Fabaceae, intercropping, yield, spontaneous vegetation 


\section{Introduction}

Okra (Abelmoschus esculentus L. Moench) is a species of the Malvaceae family with indeterminate growth. Flowering and fruiting occur throughout the plant cycle (Zucchi et al., 2012). In Brazil, this vegetable is grown mainly in the southeast and northeast regions, where the fruits are eaten green in the form of salads, fried or stewed.

In the state of Maranhão, this vegetable is of high importance for food security, where family farmers grow it generally in rotation with basic crops such as corn, beans, cassava and pumpkin. The okra yield in the São Luís Agropolo, which includes the municipalities of São Luís, Paço do Lumiar, Raposa and São José de Ribamar, was $2932 \mathrm{~kg} \mathrm{ha}^{-1}$ (Sagrima, 2017), which is considered very low compared to other northeastern states, such as Sergipe (14 $000 \mathrm{~kg} \mathrm{ha}^{-1}$ ) (Crea, 2014). This low local productivity of the crop is mainly related to the low availability of nutrients and the inadequate management of diseases, pests and spontaneous plants.

The incidence of spontaneous plants is a major biological constraint that decreases okra crop yield. Increased spontaneous plant infestation in cropping areas is generally favored by the slow initial growth of okra and by the use of wide spacings between plant rows (Santos et al., 2010; Ribeiro et al., 2011), as well as the absence of soil cover between the crop rows (Tivelli et al., 2013). In areas of okra cultivation on the Island of São Luís, weeds are usually controlled by hoe weeding, which increases their dispersion by fragmentation of vegetative structures, thus becoming one of the main biological problems.

Uncontrolled spontaneous plant growth can cause losses of 51\% (Santos et al., 2017) to 95\% (Bachega et al., 2013) in okra yield. In this context, the cultivation of okra intercropped with green manure can be an important strategy for spontaneous plant management and therefore to increase okra yield.

Green manure is recognized as a viable option in the search for the sustainability of agricultural soils, which, in addition to protection and nutrient supply, may have spontaneous plant suppression properties (Nascimento \& Matos, 2007). The reduction of spontaneous plant abundance by green manures is a direct effect of competition for environmental resources (Smith \& Gross, 2007; Pantaleão et al., 2012) and the release of allelopathic compounds (Timossi et al., 2011), which decreases herbicide use and increases the environmental sustainability of agroecosystems. However, Chieza et al. (2017) emphasized that negative effects of green manures grown in intercropping may occur if the species that make up the system are not sown and managed in the appropriate interval at the correct time of the species and the region.

Ribas et al. (2003), in okra intercropped with Crotalaria juncea under organic management, observed an increase of up to $13 \%$ in okra yield, with a contribution of $50 \%$ of nitrogen by BNF. Silva et al. (2013) noted 20 days after sowing. a reduction of spontaneous plant biomass of $90 \%, 88 \%$ and $82 \%$ when soil was covered with Pueraria phaseoloides, Glycine wightii and Arachis pintoi, respectively, while Tivelli et al. (2013) visually observed spontaneous plant suppression between the rows of the okra intercropped with green manures, particularly with Mucuna deeringiana with a $10 \%$ increase in okra yield. 
In São Luís, the use of green manures intercropped with okra is little known and practiced despite the benefits of this practice to spontaneous plant suppression and to increase yield. The reasons are due to the scarcity or lack of technical studies on the agronomic properties of green manure intercropping associated with local edaphoclimatic conditions to avoid competition with the crop. Thus, the hypothesis of this research is that the cover plants Vigna unguiculata, Crotalaria juncea, Mucuna nivea and Cajanus cajan intercropped with okra suppress spontaneous plants and increase the production of this vegetable. In view of the above, this research aimed to evaluate the viability of cover plants intercropped with okra to suppress spontaneous plants and increase vegetable productivity.

\section{Materials and Methods}

\subsection{Study Site}

The experiment was carried out from July to December 2018 in a family farmer's area of the Vegetable Pole Producer of Jardim São Cristóvão II in São Luís - MA. The local climate, according to the Köppen classification, is equatorial of the type Aw', hot and humid. The rainfall and average temperature during the experiment were $78.47 \mathrm{~mm}$ and $27.01{ }^{\circ} \mathrm{C}$, respectively (Nugeo, 2018).

The soil of the experimental area was classified as Red-Yellow Distrophic Arenic Argisol with the following chemical characteristics in the arable layer $(0-20 \mathrm{~cm}): \mathrm{pH}\left(\mathrm{CaCl}_{2}\right)=5.2$; $\mathrm{Ca}^{+2}=32 \mathrm{mmol}_{\mathrm{c}} \mathrm{dm}^{-3} ; \mathrm{Mg}^{+2}=8 \mathrm{mmol}_{\mathrm{c}} \mathrm{dm}^{-3} ; \mathrm{Al}^{+3}=26 \mathrm{mmol}_{\mathrm{c}} \mathrm{dm}^{-3} ; \mathrm{K}^{+}=0.2 \mathrm{mmol}_{\mathrm{c}} \mathrm{dm}^{-3} ; \mathrm{P}$ $=218 \mathrm{mg} \mathrm{dm}^{-3} ; \mathrm{V}=61 \%$; O.M. $=5 \mathrm{~g} \mathrm{dm}^{-3}$ (Santos et al., 2013).

The previous crop grown in the experimental area was cassava (Manihot esculenta Crantz). The soil preparation consisted of mowing the spontaneous vegetation, since the area was fallow for five months. Planting fertilization consisted of $7.5 \mathrm{t} \mathrm{ha}^{-1}$ chicken manure. A total of $80 \mathrm{~kg} \mathrm{ha}^{-1}$ of urea and $110 \mathrm{~kg} \mathrm{ha}^{-1}$ of potassium chloride were top-dressed at 20 and 40 days after crop emergence (DAE), respectively.

\subsection{Experimental Design and Application of Treatments}

The experiment was installed in a randomized complete block design with 10 treatments and four replications. The treatments were OW = okra with weeding; OSV = okra with spontaneous vegetation; OCP = okra with cowpea [Vigna unguiculata $(\mathrm{L})$. Walp.]; OSH = okra with sunn hemp (Crotalaria juncea L.); OVB = okra with velvet bean [Mucuna nivea (L.) DC.]; OPP = okra with pigeon pea [Cajanus cajan (L.) Huth]; $\mathrm{CP}=$ cowpea sole; $\mathrm{SH}=$ sunn hemp sole; $\mathrm{VB}=$ velvet bean sole; $\mathrm{PP}=$ pigeon pea sole. The treatments okra with hoe weeding (OW) and okra with spontaneous vegetation (OSV) were the okra controls with the absence of green manure.

The okra intercropped with green manures experimental plots of were composed of four rows of $3.20 \mathrm{~m}$ in length, spaced $1.0 \mathrm{~m}$ between rows and $0.40 \mathrm{~m}$ between plants within rows totaling $12.80 \mathrm{~m}^{2}$. One row of each green manure was seeded between the okra rows.

The green manure sole crop plots were composed of seven rows of $3.20 \mathrm{~m}$ spaced $0.50 \mathrm{~m}$ between rows. To evaluate the yield of okra and green manures, the two central rows of each 
plot with $4.8 \mathrm{~m}^{2}$ were considered useful areas. The okra cultivar used was Santa Cruz 47, whose seeds were immersed in water for 24 hours to break dormancy. Sowing was carried out on July 26, 2018, with four seeds per pit. To avoid competition of the green manures with the okra crop, the slowest growing dwarf pigeon pea was sown to the eight DAE of the crop and the other green manures at 14 DAE.

The green manure planting densities either as intercropping or as the sole crop were 25 seeds $\mathrm{m}^{-1}$ for cowpea, 30 seeds $\mathrm{m}^{-1}$ for sunn hemp, and four seeds $\mathrm{m}^{-1}$ for velvet bean. The seeds of the green manures were inoculated with the bacterial strain SEMIA 6462 (Bradyrhizobium spp.) at dosages of $3 \mathrm{ml} \mathrm{kg}$-1 for sunn hemp, $2.99 \mathrm{ml} \mathrm{kg}^{-1}$ for cowpea, $2.97 \mathrm{ml} \mathrm{kg}^{-1}$ for velvet bean and $3.05 \mathrm{ml} \mathrm{kg}^{-1}$ for dwarf pigeon pea. Microsprinkler irrigation was provided every three throughout the harvest cycle, but there were failures in irrigation as it was managed by the farmer. The treatments with dwarf pigeon pea were excluded due the lowest performance, low germination and slow growth.

\subsection{Data Collection}

The parameters evaluated for the green manures were vegetation cover and dry and fresh mass of the aerial part. The variables assessed for the spontaneous plants were dry mass, phytosociological parameters, species richness, and the Shannon diversity index $\left(\mathrm{H}^{\prime}\right)$. The crop was evaluated by the weight of marketable fruits $\left(\mathrm{kg} \mathrm{ha}^{-1}\right)$, plant height $(\mathrm{cm})$ and the equivalent area index (EAI).

The sampling of the vegetation cover of green manure intercropped with okra and okra with spontaneous vegetation was carried out at 7,21 and $35 \mathrm{DAE}$ of green manure by the method of the number of intersections of a $50 \mathrm{~cm}$ wooden side frame, with a network of ropes spaced every $5.0 \mathrm{~cm}$ (Alvarenga, 1993). At each intersection between two perpendicular slopes, a point was defined that represented an area when placed on the vegetation cover of the plots.

The fresh mass of the green manure intercropped and sole was sampled in the flowering time by launching a $0.25 \mathrm{~m}^{2}$ open quadrat three times in each plot. The samples were placed in an oven-dried oven with forced air ventilation at $65^{\circ} \mathrm{C}$ for 72 hours to determine the dry mass on a precision scale of $0.01 \mathrm{~g}$. Sunn hemp was collected at 43 days after sowing (DAS), cowpea at 48 DAS and velvet bean at 62 DAS. Spontaneous plants were also collected in the flowering stage of green manures by launching a $0.25 \mathrm{~m}^{2}$ open quadrat three times in each plot.

Spontaneous plants within the quadratic perimeter were separated, counted and identified with the aid of an identification manual regarding family, genus, species and dicotyledonous and monocotyledonous species. The spontaneous plants were dried in an oven with forced ventilation at $65{ }^{\circ} \mathrm{C}$ for 72 hours to obtain the dry mass that was weighed on a scale with an accuracy of $0.01 \mathrm{~g}$.

Density, frequency and dry matter data of the spontaneous vegetation were used to determine the phytosociological parameters: relative density $(\mathrm{RD})$, relative frequency (RFr), relative dominance (RDo) and importance value index (IVI) of each species.

The relative density refers to the percentage of individuals of a species in relation to the total 
of individuals of the community; the relative frequency refers to the percentage representing the frequency of a population in relation to the sum of the frequencies of all species constituting the community; relative dominance is the relationship between the weight of the dry mass accumulated by a species and the weight of the total dry mass of the spontaneous plant species community, and the importance value index is the sum of the RD, RFr and RDo, which are the three fundamental factors in determining the importance of a species in relation to its community (Pitelli, 2000).

We also determined the spontaneous vegetation species richness of based on the number of species identified and their diversity among the populations through the Shannon-Weaver diversity index $\left(\mathrm{H}^{\prime}\right)$, which reflects two basic attributes: number of species and equitability (Pinto-Coelho, 2000).

The number of species refers to species richness, and equitability corresponds to the uniform distribution of individuals of different species. This index was calculated considering the populations' shares in terms of numbers of individuals by the formula: $\mathrm{H}^{\prime}=-\Sigma$ pi ln pi, where $\ln$ is the neperian logarithm; $\mathrm{pi}=\mathrm{ni} / \mathrm{N}$; ni is the total number of sampled individuals.

The height of the okra was determined at $60 \mathrm{DAE}$, and at harvest, the okra fruits were harvested manually every two days, when they had a commercial length between $12.0 \mathrm{~cm}$ and $15.0 \mathrm{~cm}$. To evaluate the intercropping efficiency in relation to the okra and green manures, only the equivalence area index (EAI) was determined. The EAI was obtained by the formula EAI = $(\mathrm{Ogm} / \mathrm{Ow})+(\mathrm{GMo} / \mathrm{GMs})$, where Ogm = yield of the okra with green manure $\left(\mathrm{kg} \mathrm{ha}^{-1}\right)$; Ow = yield of the okra with hoe weeding; GMo = fresh mass of green manure with okra $\left(\mathrm{kg} \mathrm{ha}^{-1}\right)$; GMs $=$ fresh mass of sole green manure $\left(\mathrm{kg} \mathrm{ha}^{-1}\right)$. An EAI of 1.0 indicates that there is no difference in yield in intercropping when compared to crop alone. Any value greater than 1.0 indicates a yield advantage for intercropping, a result called over productivity (Gliessman, 2000).

\subsection{Data Analysis}

The dry mass data of green manures and spontaneous vegetation species richness, coverage of okra and intercropped cover plants, the Shannon-Weaver diversity index $\left(\mathrm{H}^{\prime}\right)$, plant height and okra yield were subjected to analysis of variance (ANOVA) using the F test, and the means were compared by the Scott - Knott test at 5\% probability. The statistical program used was Agroestat (Barbosa \& Maldonado Júnior, 2010).

\section{Results and Discussion}

\subsection{Floristic Composition of the Spontaneous Plants}

The treatment of okra and spontaneous vegetation (OSV) presented a total of 32 species, of which $22 \%$ to $37.5 \%$ did not occur in green manures either intercropped or sole crop (Table 1). The spontaneous vegetation associated with the okra crop presented high species richness that was decreased by green manure, probably due to competition for environmental resources. Smith \& Gross (2007) pointed out that green manure represents an important biological management potential because it competes with spontaneous plants for light, space, nutrients, and water, therefore decreasing the abundance potential of these species. 


\section{Macrothink

The botanical group that predominated in okra with spontaneous vegetation (OSV) was dicotyledonous, with 22 species that were suppressed in $32 \%$ to $50 \%$ by the green manure intercropped and sole crop. In contrast, the monocotyledonous group with 10 species was not suppressed by green manures (Table 1). Greater importance and suppression of the dicotyledonous species group in okra with green manures were observed. Bachega et al. (2013) and Santos et al. (2017) also demonstrated the relevance of this botanical group of spontaneous vegetation in okra cultivation.

Although green manures did not negatively affect the species of the monocotyledonous group, it should be emphasized that this group requires attention, since they are difficult to manage due to high seed production, tillering capacity, and vegetative propagation structures. Pantaleão et al. (2012), in an experiment with green manures, also observed that the legumes did not suppress the species of the monocotyledonous group.

Table 1. List of spontaneous plants found in the okra with spontaneous vegetation, okra intercropped with green manures and sole green manures. São Luís - MA, 2018. OSV= okra with spontaneous vegetation; $\mathrm{C}=$ cowpea; $\mathrm{SH}=$ sunn hemp; $\mathrm{VB}=$ velvet bean

\begin{tabular}{|c|c|c|c|c|c|c|c|}
\hline \multirow[t]{3}{*}{ Family / Species } & \multirow[b]{3}{*}{ OSV } & \multicolumn{6}{|c|}{ Green manure } \\
\hline & & \multicolumn{3}{|c|}{ Intercropped } & \multicolumn{3}{|c|}{ Sole } \\
\hline & & $\mathrm{C}$ & SH & VB & $\mathrm{C}$ & SH & VB \\
\hline \multicolumn{8}{|c|}{ Monocotyledonous } \\
\hline \multicolumn{8}{|l|}{ Commelinaceae } \\
\hline Commelina benghalensis $\mathrm{L}$. & $\mathrm{X}$ & $\mathrm{X}$ & $\mathrm{X}$ & $\mathrm{X}$ & $\mathrm{X}$ & $\mathrm{X}$ & $\mathrm{X}$ \\
\hline \multicolumn{8}{|l|}{ Cyperaceae } \\
\hline Cyperus sphacelatus Rottb. & $\mathrm{X}$ & $\mathrm{X}$ & $\mathrm{X}$ & $\mathrm{X}$ & $\mathrm{X}$ & $\mathrm{X}$ & $\mathrm{X}$ \\
\hline Cyperus surinamensis Rottb. & $\mathrm{X}$ & $\mathrm{X}$ & $\mathrm{X}$ & $\mathrm{X}$ & $\mathrm{X}$ & $\mathrm{X}$ & $\mathrm{X}$ \\
\hline Cyperus diffusus Vahl. & $\mathrm{X}$ & $\mathrm{X}$ & $\mathrm{X}$ & $\mathrm{X}$ & $\mathrm{X}$ & $\mathrm{X}$ & $\mathrm{X}$ \\
\hline \multicolumn{8}{|l|}{ Poaceae } \\
\hline Digitaria ciliaris (Retz). Koeler & $\mathrm{X}$ & $\mathrm{X}$ & $\mathrm{X}$ & $\mathrm{X}$ & $\mathrm{X}$ & $\mathrm{X}$ & $\mathrm{X}$ \\
\hline Dactyloctenium aegyptium (L.) Willd. & $\mathrm{X}$ & $\mathrm{X}$ & $\mathrm{X}$ & $\mathrm{X}$ & $\mathrm{X}$ & $\mathrm{X}$ & $\mathrm{X}$ \\
\hline Eleusine indica (L.) Gaertn & $\mathrm{X}$ & $\mathrm{X}$ & $\mathrm{X}$ & $\mathrm{X}$ & $\mathrm{X}$ & $\mathrm{X}$ & --- \\
\hline Eragrostis ciliaris (L.) R. Br. & $X$ & $\mathrm{X}$ & $\mathrm{X}$ & $\mathrm{X}$ & $\mathrm{X}$ & $\mathrm{X}$ & $\mathrm{X}$ \\
\hline Eragrostis airoides Nees. & $\mathrm{X}$ & $\mathrm{X}$ & -- & --- & $\mathrm{X}$ & $\mathrm{X}$ & --- \\
\hline Panicum trichoides $\mathrm{L}$. & $\mathrm{X}$ & $\mathrm{X}$ & $\mathrm{X}$ & $\mathrm{X}$ & $\mathrm{X}$ & --- & $\mathrm{X}$ \\
\hline
\end{tabular}

Dicotyledonous

Amaranthaceae

Alternanthera tenella Colla

X $\quad$ X $\quad$ X $\quad$ X

X $\quad$ X $\quad$ X

Amaranthus lividus L.

Asteraceae

Eclipta alba (L.) Hassk.

Emilia coccinea L.

Emilia spp.

Praxelis pauciflorum (Kunth) R.M

King \& H. Rob.

$\begin{array}{llll}X & X & X & X \\ X & -----\end{array}$

$---\quad---\quad---$

$\begin{array}{llll}X & --- & --- & -- \\ X & X & X & \text { X } \\ X & X & X & \text { X }\end{array}$

$X \quad X \quad X$

$X \quad X \quad X$ 
Synedrella nodiflora (L.) Gaertn. 2020, Vol. 8, No. 4

Boraginaceae

Heliotropium indicum L.

Cleomaceae

Hemiscola aculeata (L.) Raf.

Euphorbiaceae

Chamaesyce hirta (L.) Millsp.

Euphorbia heterophylla L.

Fabaceae

Indigofera hirsuta L.

Mimosa nuttalli $\mathrm{L}$.

Mimosa pudica L.

Lamiaceae

Malvaceae

Corchorus olitorius L.

Sida spp.

Molluginaceae

Mollugo verticillata $\mathrm{L}$.

Phyllanthaceae

Phyllanthus niruri L.

Rubiaceae

Spermacoce latifolia Aubl.

Spermacoce verticillata $\mathrm{L}$.

Turneraceae

Turnera ulmifolia L.

\begin{tabular}{ccccccc}
$\mathrm{X}$ & $\mathrm{X}$ & $\mathrm{X}$ & $\mathrm{X}$ & $\mathrm{X}$ & $\mathrm{X}$ & $\mathrm{X}$ \\
$\mathrm{X}$ & --- & --- & --- & --- & $\mathrm{X}$ & --- \\
& & & & & & \\
$\mathrm{X}$ & --- & --- & --- & $\mathrm{X}$ & --- & -- \\
& & & & & & \\
$\mathrm{X}$ & $\mathrm{X}$ & $\mathrm{X}$ & $\mathrm{X}$ & $\mathrm{X}$ & $\mathrm{X}$ & $\mathrm{X}$ \\
$\mathrm{X}$ & $\mathrm{X}$ & --- & --- & $\mathrm{X}$ & --- & -- \\
& & & & & & \\
$\mathrm{X}$ & $\mathrm{X}$ & --- & $\mathrm{X}$ & --- & --- & -- \\
$\mathrm{X}$ & --- & --- & $\mathrm{X}$ & $\mathrm{X}$ & --- & -- \\
$\mathrm{X}$ & $\mathrm{X}$ & $\mathrm{X}$ & --- & $\mathrm{X}$ & --- & $\mathrm{X}$ \\
& & & & & & \\
$\mathrm{X}$ & $\mathrm{X}$ & $\mathrm{X}$ & $\mathrm{X}$ & $\mathrm{X}$ & $\mathrm{X}$ & $\mathrm{X}$ \\
& & & & & & \\
$\mathrm{X}$ & $\mathrm{X}$ & --- & $\mathrm{X}$ & $\mathrm{X}$ & $\mathrm{X}$ & $\mathrm{X}$ \\
$\mathrm{X}$ & --- & $\mathrm{X}$ & $\mathrm{X}$ & --- & --- & -- \\
& & & & & & \\
$\mathrm{X}$ & $\mathrm{X}$ & $\mathrm{X}$ & --- & $\mathrm{X}$ & $\mathrm{X}$ & $\mathrm{X}$ \\
& & & & & & \\
$\mathrm{X}$ & $\mathrm{X}$ & --- & $\mathrm{X}$ & $\mathrm{X}$ & $\mathrm{X}$ & $\mathrm{X}$ \\
& & & & & & \\
$\mathrm{X}$ & $\mathrm{X}$ & $\mathrm{X}$ & $\mathrm{X}$ & $\mathrm{X}$ & $\mathrm{X}$ & $\mathrm{X}$ \\
$\mathrm{X}$ & $\mathrm{X}$ & $\mathrm{X}$ & $\mathrm{X}$ & --- & --- & $\mathrm{X}$ \\
& & & & & & \\
$\mathrm{X}$ & --- & --- & $\mathrm{X}$ & $\mathrm{X}$ & $\mathrm{X}$ & $\mathrm{X}$ \\
\hline & & & & & &
\end{tabular}

\subsection{Species Richness and Diversity of the Spontaneous Plants}

The spontaneous species richness differed significantly between the treatments, and lower values were observed in the okra with sunn hemp (12.75), sole sunn hemp (13.50) and velvet bean sole (11.75) (Figure 1). The lowest number of spontaneous species in sunn hemp treatments can be attributed to their rapid growth and shading of the soil that affected the germination and development of these species. Sun hemp has fast and vigorous growth and therefore has been used as green manure, aiming at the maintenance and improvement of soil physical and chemical properties and suppression of spontaneous plants (Teodoro et al., 2011; Puiatti et al., 2015).

For velvet bean sole crops, the decrease in the number of spontaneous species is possibly due to their habit of prostrate growth that blocks sunlight, inhibiting the germination and growth of these species. Wutke et al. (2014) emphasized that the velvet bean has fast growth, with greater production of biomass and cover and faster soil protection promoting spontaneous plant control. It is noteworthy that the intercropped velvet bean had its branches cut to prevent the stifling of the okra crop, which may have affected its suppressive effect and increased the number of spontaneous plants. 


\section{Ml Macrothink}

The species diversity was determined by the Shannon diversity index $\left(\mathrm{H}^{\prime}\right)$, and there was no significant difference between treatments. Therefore, green manures did not influence the distribution of individuals of different species of spontaneous vegetation (equitability), as they negatively affected species richness (Figure 1), the other basic attributes of the Shannon index. Smith et al. (2015) reported that one way that cover-crop-specific filtering effects could manifest among the treatments is in differences in resident weed community species richness and diversity.

In addition, the diversity values ranged from $\mathrm{H}^{\prime}=1.71$ (okra with sunn hemp) to $\mathrm{H}^{\prime}=2.14$ (sole cowpea), placing spontaneous vegetation with average diversity since the minimum value of the Shannon index that indicates no diversity is 1.0 and the maximum between 3.0 and 4.0 (Gliessman, 2000). The green manure used by Lima et al. (2014) provided Shannon's diversity index of spontaneous vegetation of $\mathrm{H}^{\prime}=1.8$, which decreased with the development of cover plants, as many species with less competitive ability were suppressed.

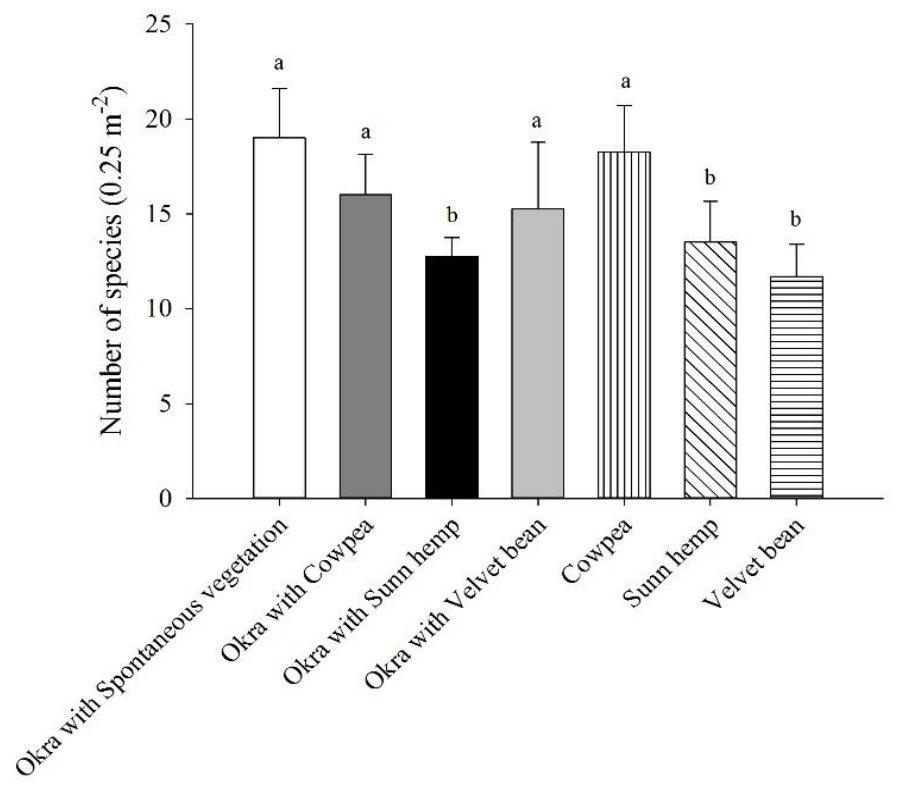

Figure 1. Spontaneous plant species richness in okra with spontaneous vegetation, okra intercropped with green manures and sole green manures. São Luís - MA, 2018. Means followed by the same letter in columns are not different by the Scott-Knott test $(p<0.05)$

\subsection{Importance Value Index of the Spontaneous Plants}

The species with the highest importance value index (IVI) in the okra treatment with spontaneous vegetation was E. ciliaris (60.39\%), followed by A. tenella $(31.99 \%)$, S. nodiflora (23.82\%) and C. benghalensis (18.36\%); the other species corresponded to $165.44 \%$ (Figure 2). The genus Eragrostis spp. (Iyagba \& Ibe, 2013), which is characterized by annual species, reproduction by seeds, and the $\mathrm{C} 4$ photosynthesis cycle, which is relevant within a complex of spontaneous plants (Kissman, 1997). The other species, A. tenella, S. nodiflora, and $C$. benghalensis, are also important spontaneous plants found in okra crops (Awodoyin \& Olubode, 2009; Santos et al., 2017). 


\section{Mll Macrothink}

Comparing okra with spontaneous vegetation and the green manure treatments, a greater reduction of IVI of E. ciliaris was observed by okra intercropped with cowpea (IVI = $17.41 \%$ ), followed by intercropping with velvet bean (IVI $=32.79 \%$ ). The species A. tenella, $S$. nodiflora, and $C$. benghalensis increased their IVIs in treatments with green manures; however, the other species were suppressed by treatments with green manures, mainly okra with sunn hemp (IVI $=109.09 \%$ ) and velvet bean (IVI $=125.14 \%$ ) (Figure 2). Green manures changed the dynamics of spontaneous vegetation intercropped with the crop and sole by changing the conditions of humidity and light that affected the infestation of E. ciliaris but did not suppress A. tenella, S. nodiflora and C. benghalensis.

Beltrán et al. (2012) reported that the presence of a plant species may facilitate or favor the establishment of another species by modifying the environment, making it more favorable to its establishment and survival. Smith et al. (2015) pointed out that suppression studies of spontaneous plants with green manure should consider that sometimes a particular spontaneous species does not have its growth hindered but facilitated by the specific cover plant.

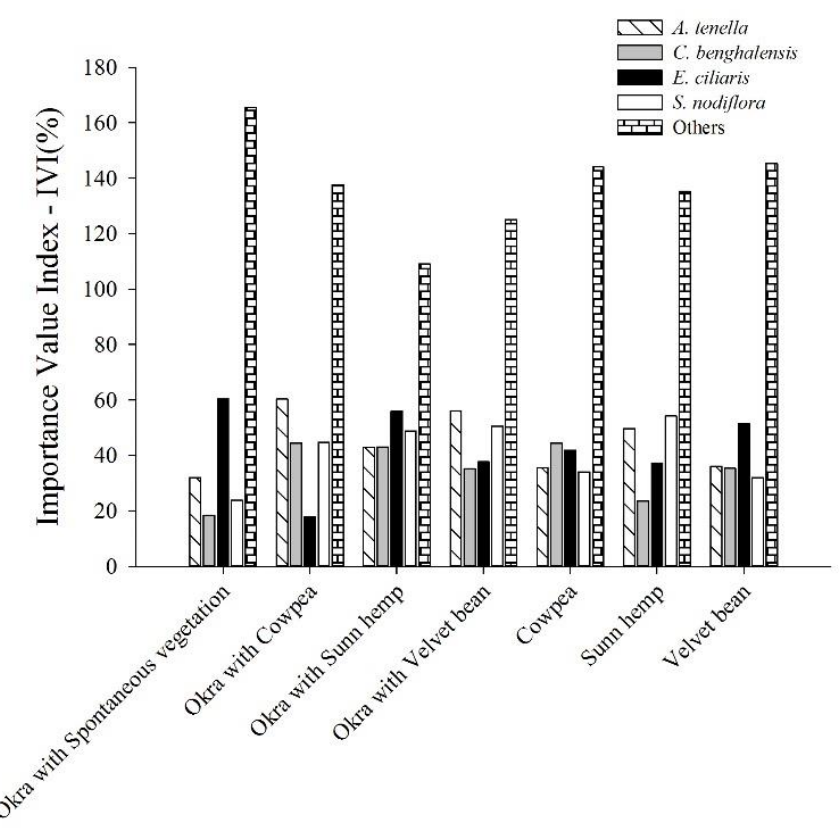

Figure 2. Importance value index (IVI) of the main spontaneous plants in the okra with spontaneous vegetation, okra intercropped with green manures and sole green manures. São Luís - MA, 2018

\subsection{Dry Mass of Green Manures of the Spontaneous Plants}

The green manure treatments differed with respect to dry mass production, and sunn hemp intercropped with okra (5 $245 \mathrm{~kg} \mathrm{ha}^{-1}$ ) and sole (4 $220.5 \mathrm{~kg} \mathrm{ha}^{-1}$ ) presented the highest mean values. However, the dry matter accumulation of the spontaneous plants did not differ between treatments with green manures, whose highest dry mass production occurred in the okra with spontaneous vegetation (Figure 3). The largest dry matter production of sunn hemp is explained by its rapid growth and flowering at 48 days after sowing (DAS) and the lowest leaf/stalk ratio. 


\section{Macrothink Institute ${ }^{\mathrm{TM}}$}

However, the other green manures were also effective in suppressing the dry mass of spontaneous plants. Pantaleão et al. (2012) and Timossi et al. (2011) reported that the lower accumulation of dry matter by spontaneous plants is related to the faster initial development of green manures that competes with spontaneous plants for environmental resources.

Comparing the accumulation of a dry mass of spontaneous vegetation associated with okra $\left(952.53 \mathrm{~kg} \mathrm{ha}^{-1}\right)$ with the other treatments, there was a greater reduction in the dry mass of spontaneous plants by sole green manure, cowpea (57.05\%), sunn hemp (60.25\%) and velvet bean (66.49\%) (Figure 3). The absence of green manure allowed greater solar radiation incidence on the soil surface, which stimulated germination, growth, and the full development of spontaneous plants, resulting in greater dry mass accumulations, which were impaired in the presence of green manure.

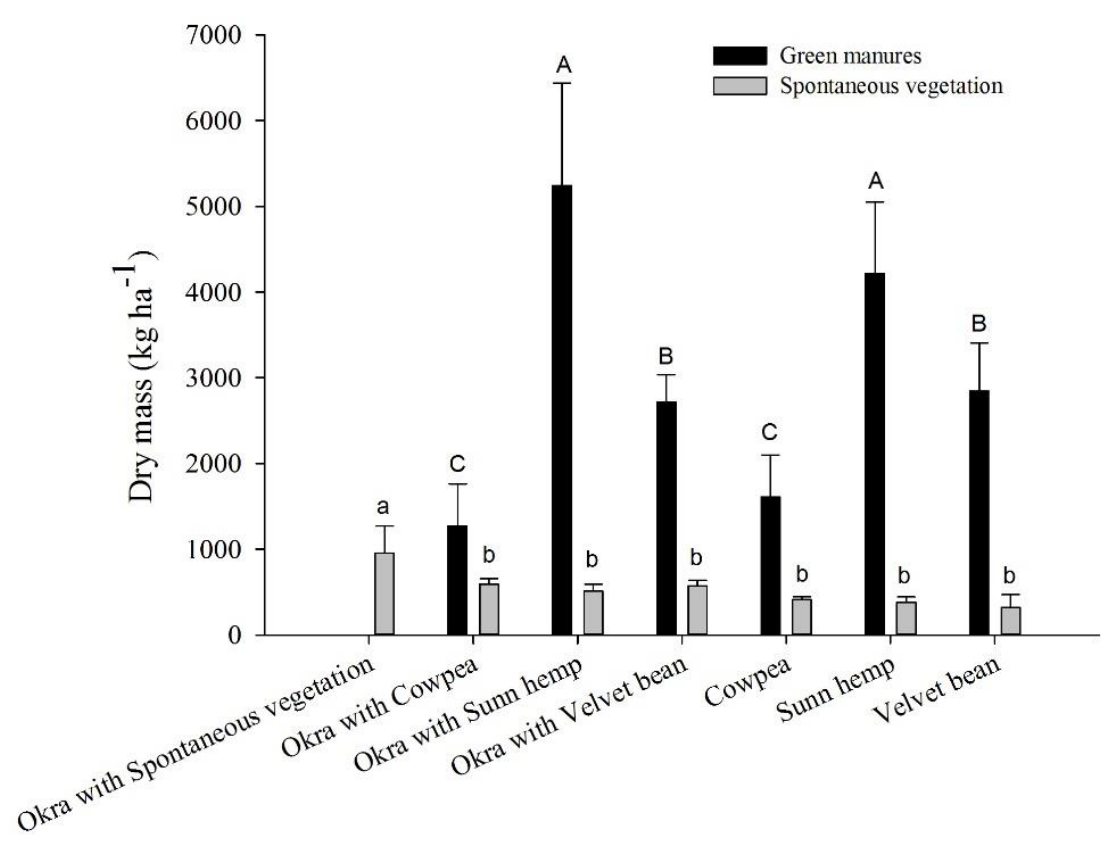

Figure 3. Dry mass $\left(\mathrm{kg} \mathrm{ha}^{-1}\right)$ of green manures and spontaneous vegetation $\left(\mathrm{kg} \mathrm{ha}^{-1}\right)$ in green manures intercropped with okra and sole. Means followed by the same letter in the column do not differ by the Scott - Knott test $(\mathrm{p}<0.05)$

\subsection{Vegetal Cover of the Crop and Intercropping With Green Manure}

The highest percentages of soil cover by okra were in intercropping with green manures, which did not differ only at 7 DAE. Among green manures, there was a higher percentage of soil coverage by okra in intercropping with sunn hemp at $21 \mathrm{DAE}(17.65 \%)$ and $35 \mathrm{DAE}$ $(18 \%)$. However, the lowest percentage was in the okra and spontaneous vegetation at 7 DAE with $1.5 \%$ (Figure $4 a$ ).

The crop coverage for soil shading was very low in the first assessment, a behavior that is related to its slow initial growth that favors the emergence of weeds that increase the cost of 
production (Santos et al., 2010). From 21 DAE, it increased in all treatments, but with lower percentages in the treatment with spontaneous vegetation, which indicates that the culture is sensitive to the interference of these species.

The highest percentages of soil cover by the crop in the presence of green manures show its important biological management of spontaneous vegetation through competition for light, space, nutrients, and water, reducing the potential for an abundance of this vegetation (Smith \& Gross, 2007).

Regarding the soil cover by green manures, it was noted that they differed at 35 DAE, with the highest percentages of soil cover by sunn hemp (62\%) and velvet bean (55.58\%). However, spontaneous vegetation in the okra with spontaneous vegetation showed the highest percentages of soil coverage, reaching 35 DAE, 92\% coverage (Figure 4b).

The high vegetation cover of the spontaneous plants showed that these species are well adapted to the local conditions and that among the green manures, sunn hemp and velvet bean presented the greater potential for soil cover and suppression of these plants due to the high dry mass production. Teodoro et al. (2011), when assessing the soil cover rate by the velvet bean, observed coverage of $63 \%$ and for sunn hemp an accelerated development rate of $47.7 \%$ at 40 DAS. This suggests the efficiency of occupation/land cover by these species in the first 30 days, which can favor the development of the crop that presents a critical period of competition from spontaneous vegetation from 12 to 36 DAE (Santos et al., 2017).
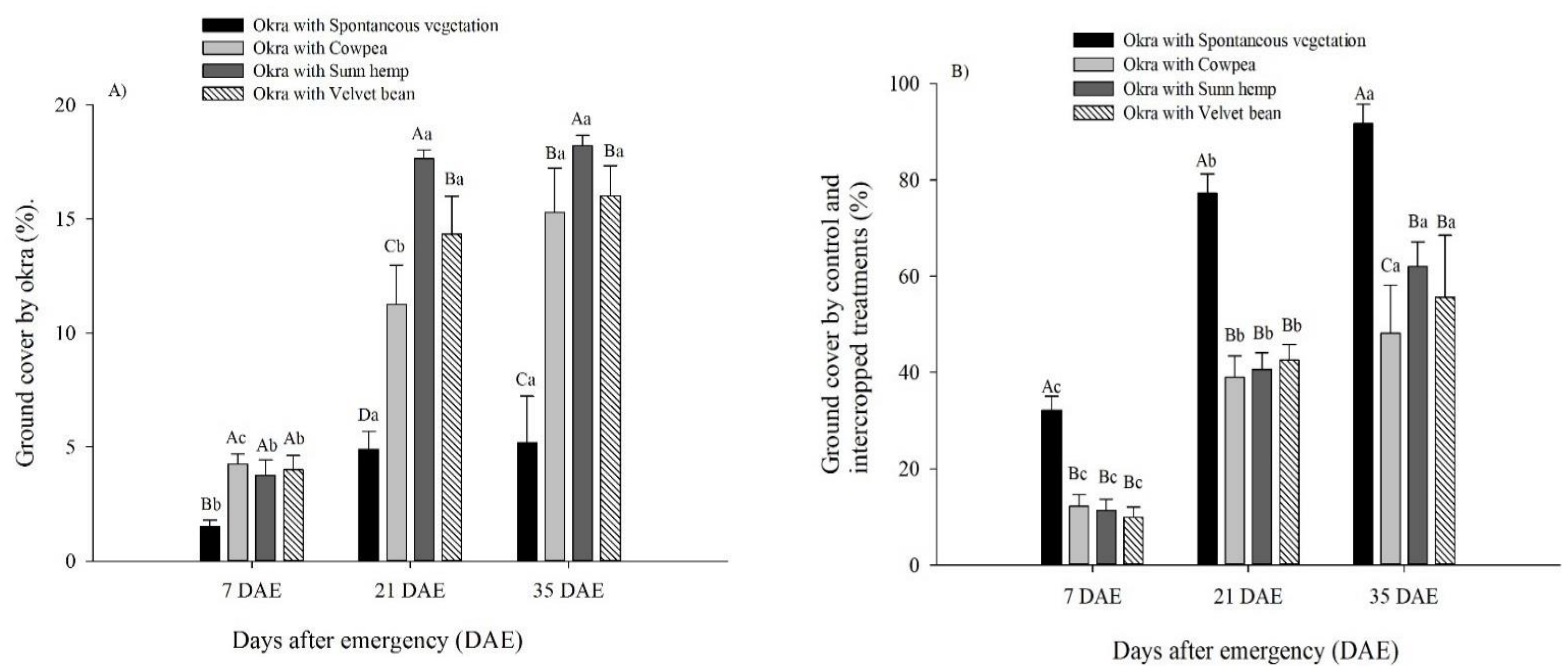

Figure 4. a) Ground cover by okra; b) soil cover by spontaneous vegetation and green manures at different times after the emergence of green manures. São Luís-MA, 2018. Averages followed by the same lowercase letter compare treatments between assessments, and uppercase letters compare treatments within each assessment by the Scott - Knott test $(\mathrm{p}<0.05)$

\subsection{Plant Height, Crop Yield and Equivalent Area Index}

The height of the okra at 60 DAE did not differ significantly between treatments, okra weeding, okra intercropping with cowpea, and velvet bean, where the highest heights were 
found. The okra with spontaneous vegetation reduced its height by $20.65 \%$ and with crotalaria by $13.44 \%$ when compared to the treatment okra with weeding (Table 2 ).

The higher heights of okra are explained in the intercropping of green manures, cowpea and velvet bean due to the habit of prostrate growth of these species; however, the heights were low compared to those obtained by Silva et al. (2013) at 80 DAS in soil covered with perennial soybean, tropical kudzu, and stylosantes that obtained okra heights between 60 and $80 \mathrm{~cm}$. The lower height of the okra in the research is attributed to the presence of nematodes in the area and the deficiency of irrigation that impaired the productivity of the crop.

Green manure intercropped with okra did not increase crop productivity when compared to the control treatment. However, in relation to the productivity of okra with spontaneous vegetation, there were yield gains of $93 \%$ for okra intercropping with cowpea, $92 \%$ for okra with sunn hemp, and $94.5 \%$ for okra with velvet bean (Table 2).

The rapid development and aggressiveness of green manure on spontaneous vegetation contributed to reducing the suppressive effect of these species on okra production but did not increase crop productivity compared to okra with weeding. Chieza et al. (2017) intercropped corn with Crotalaria juncea at different sowing and management intervals and found negative effects on crop production in the summer, which was attributed to competition for water, nutrients, and light. Puiatti et al. (2015) highlighted that the careful choice of the green manures that compose the intercropping, the time of their respective installations and the management of the cut or pruned mass are of fundamental importance to provide maximum exploitation of the advantages of the intercropping system.

The partial equivalent area index (EAI) of the okra was below 1.0 in all intercropping with green manures, but the partial EAI of green manures and the total EAI were higher than 1.0 with emphasis on the intercropping of the okra with sunn hemp (Table 2). The positive interference of green manure in intercropping with the crop in reducing the biomass of spontaneous plants was superior to any interspecific competition that has occurred. Gliessman (2000) pointed out that when the total EAI is greater than 1.5 or when the partial EAI of an intercropping member is greater than 1.0, there is strong evidence that negative interference is minimal in the interactions of the intercropping.

Odedina et al. (2014), in intercropping okra with four varieties of cowpea, also observed low partial EAI of okra $(0.63 ; 0.46 ; 0.25$ and 0.52$)$; however, the partial EAI of the cowpea varieties and the total EAI were greater than 1.0. Tivelli et al. (2013), in okra cultivation intercropped with two lines of Mucuna deeringiana, mentioned a total EAI of 1.56 and Crotalaria spectabilis of 1.6 .

Despite the positive aspect of the suppression of spontaneous vegetation by green manures, the low EAI of the okra in the intercropping suggests the need to adapt the arrangements to increase the performance of the crop, such as increasing the planting interval from 14 to 21 $\mathrm{DAE}$ of the green manures. 
Table 2. Okra height, mean total production (MTP), okra equivalent area index (EAI), green manures with okra (oGM), sole green manures (sGM), green manure equivalent area index (gmEAI) and total equivalent area index (tEAI). São Luís-MA, 2018

\begin{tabular}{lllllllc}
\hline \multicolumn{1}{c}{ Treatments } & $\begin{array}{c}\text { Okra Height } \\
(\mathrm{cm})\end{array}$ & $\begin{array}{c}\text { MTP } \\
\left(\mathrm{kg} \mathrm{ha}^{-1}\right)\end{array}$ & oEAI & $\begin{array}{l}\text { oGM } \\
\left(\mathrm{kg} \mathrm{ha}^{-1}\right)\end{array}$ & $\begin{array}{l}\text { sGM } \\
\left(\mathrm{kg} \mathrm{ha}^{-1}\right)\end{array}$ & gmEAI & tEAI \\
\hline Control (Okra with weeding) & $56.93 \mathrm{a}$ & $1365.11 \mathrm{a}^{*}$ & & - & - & - & - \\
Okra with Spontaneous Veg. & $45.71 \mathrm{~b}$ & $51.18 \mathrm{~d}$ & & - & - & - & - \\
Okra with Cowpea & $57.57 \mathrm{a}$ & $725.08 \mathrm{c}$ & 0.53 & $5132.12^{* *}$ & 4367.61 & 1.19 & 1.72 \\
Okra with Sunn hemp & $49.28 \mathrm{~b}$ & $620.06 \mathrm{c}$ & 0.45 & 10524.80 & 6723.92 & 1.57 & 2.02 \\
Okra with Velvet bean & $58.03 \mathrm{a}$ & $932.16 \mathrm{~b}$ & 0.68 & 7166.11 & 5529.85 & 1.30 & 1.98 \\
$\mathrm{CV}(\%)$ & 11.45 & 15.53 & & & & & \\
\hline
\end{tabular}

*Means followed by the same letter in columns are not different by the Scott - Knott test $(\mathrm{p}<0.05)$. **Average of three collections for each block.

\section{Conclusions}

Green manure can be a viable alternative for the agroecological management of spontaneous vegetation in okra, but further studies on the adequacy of the cover plant arrangement are necessary to provide increased productivity.

\section{Acknowledgments}

We thank to the Research Support Foundation in the State of Maranhão, Brazil (FAPEMA) for funding the research, to the Coordination for the Improvement of Higher Education Personnel (CAPES) for granting the scholarship to the first author, to Piraí - Sementes Ltda. for donating the green manure seeds and to the farmer Pedro Ribeiro Carlos de Sousa for the assignment of the area to carry out the experiment.

\section{References}

Alvarenga, R. C. (1993). Potencialidades de adubos verdes para conservação e recuperação de solos. Tese de Doutorado. Universidade Federal de Viçosa, Viçosa. 112p.

Awodoyin, R. O., \& Olube, O. S. (2009). On-field Assessment of critical period of spontaneous plants interference in okra (Abelmoschus esculentus (L.) Moench) field in Ibadan, a rainforest-savana transition eco-zone of Nigeria. Asian Journal of Food and Agro-Industry (special issue): S288-S296.

Bachega, L. P. S., Carvalho, L. B., Bianco, S., \& Filho, A. B. C. (2013). Períodos de interferência de plantas daninhas na cultura do quiabo. Planta Daninha, 31, 63-70. https://doi.org/10.1590/S0100-83582013000100007

Barbosa, J. C., \& Maldonado Jr., W. (2010). Experimentação agronômica \& AgroEstat: sistema para análises estatísticas de ensaios agronômicos. CD-ROM.

Beltrán, E., Valiente-Banuet, A., \& Verdú, M. (2012). Trait divergence and indirect interactions allow facilitation of congeneric species. Annals of Botany, 110(7), 1369-1376. 
https://doi.org/10.1093/aob/mcs089

Chieza, E. D., Guerra, J. G. M., Araújo, E. S., Espíndola, J. A., \& Fernandes, R. C. (2017). Produção e aspectos econômicos de milho consorciado com Crotalária juncea L. em diferentes intervalos de semeadura, sob manejo orgânico. Revista Ceres, 64(2), 189-196. https://doi.org/10.1590/0034-737x201764020012

Crea (2014). Conselho Regional de Engenharia e Agronomia de Sergipe. Available in: http://www.crea-se.org.br/caninde-produz-142-toneladas-de-quiabo/. (Accessed 16 June 2019).

Gliessman, S. R. (2000). Agroecologia: processos ecológicos em agricultura sustentável. (4th ed.). Porto Alegre. p.654.

Iyagba, A. G., \& Ibe, A. E. (2013). Influence of spontaneous plants interference duration on the yield and viscosity of okra (Abelmoschus esculentus (L) Moench) varieties in south-eastern Nigeria. Journal of Agricultural and Biological Science, 8(12), 793-799.

Kissmann, K. G. (1997). Plantas infestantes e nocivas. (2nd ed.). São Paulo, Basf, Tomo I. p. 824.

Lima, S. F., Timossi, P. C., Almeida, D. P., \& Silva, U.R. (2014). Fitossociologia de plantas daninhas em convivência com plantas de cobertura. Revista Caatinga, 27(2), 37-47.

Nascimento, A.F., \& Mattos, J. L. S. (2007). Produtividade de biomassa e supressão de plantas espontâneas por adubos verdes. Agroecología, 2, 33-38.

Núcleo Geoambiental (2018). Available in: https://www.nugeo.uema.br/. (Accessed 24 december 2018).

Odedina, J. N., Fabunmi, T. O., Adigbo, S. O., Odedina, S. A., \& Kolawole, R. O. (2014). Evaluation of cowpea varieties (Vigna unguiculata L. Walp) for intercropping with okra (Abelmoschus esculenthus L. Moench). American Journal of Research Communication, 2(2), 91-108.

Pantaleão, P. S., Laca-Buendia, J. P., Brito, L. F., Godinho, N. C. A., \& Bernardes, A. G. (2012). Supressão de plantas daninhas pela cobertura com adubos verdes em solo do cerrado. FAZU em Revista, 9, 30-43.

Pinto-Coelho, R. M. (2000). Fundamentos em ecologia. Porto Alegre: Artmed. p. 252.

Pitelli, R. (2000). Estudos fitossociológicos em comunidades infestantes de agroecossistemas. Jornal Consherb, 1, 1-7.

Puiatti, M., Oliveira, N. L. C., Cecon, P. R., \& Bhering, A. S. (2015). Consorciação de taro e crotalária manejada com corte rente ao solo e poda na altura do dossel. Revista Ceres, 62(3), 275-283. https://doi.org/10.1590/0034-737X201562030007

Ribas, R. G. T., Junqueira, R. M., Oliveira, F. L., Guerra, J. G. M., Almeida, D. L., Alves, B. J. R., \& Ribeiro, R. L. D. (2003). Desempenho do quiabeiro (Abelmoschus esculentus) 
consorciado com Crotalaria juncea sob manejo orgânico. Agronomia, 37(2), 80-84.

Ribeiro, L. S., Corrêa, M. J. P., Arruda, S. C., \& Costa, E. A. (2011). Banco de sementes de plantas espontâneas na cultura do quiabo no município de São Luís - MA. Cadernos de Agroecologia, 6(2), $\quad 1-5 . \quad$ Available $\quad$ in http://revistas.aba-agroecologia.org.br/index.php/cad/article/view/11057> (Accessed 23 september 2020)

Sagrima (2017). Secretaria de Estado da Agricultura, Pecuária e Pesca do Estado do Maranhão. Relatório da cadeia produtiva da hortifruticultura. p.51.

Santos, H. G., Jacomine, P. K. T., Anjos, L. H. C., Oliveira, V. A. V., Lumbreras, J. F., Coelho, M. R., Almeida, J. A., Cunha, T. J. F., \& Oliveira, J. B. (2013). Sistema brasileiro de classificação de solos. (3rd ed.). Brasília: Embrapa. p. 353.

Santos, J. B., Silveira, T. P., Coelho, P. S., Costa, O. G., Matta, P.M., Silva, M. B., \& Drumond Neto, A. P. (2010). Interferência de plantas daninhas na cultura do quiabo. Planta Daninha, 28(2), 255-262. https://doi.org/10.1590/S0100-83582010000200004

Santos, R. N. V., Rodrigues, A. A. C., Silva, M. R. M., Correa, M. J. P., \& Mesquita, M. L. R. (2017). Phytosociology and spontaneous plants interference in okra under organic cropping system. African Journal of Agricultural Research, 12(4), 251-259. https://doi.org 10.5897/AJAR2016.11888

Silva, D. M. N., Oliveira, F. L., Grazziotti, P. H., Fávero, C., \& Quaresma, M. A. L. (2013). Organic cultivation of okra with ground cover of perennial herbaceous legumes. Horticultura Brasileira, 31(3), 450-456. https://doi.org/10.1590/S0102-05362013000300017

Smith, R. G., \& Gross, K. L. (2007). Assembly of weed communities along a crop diversity $\begin{array}{llll}\text { gradient. Journal of Applied Ecology, 44(5), 1046-1056. } & \text { of }\end{array}$ https://doi.org/10.1111/j.1365-2664.2007.01335.x

Smith, R. G., Atwood, L.W., Pollnac, F. W., \& Warren, N. D. (2015). Cover-crop species as distinct biotic filters in weed community assembly. Weed Science, 63(1), 282-295. https://doi.org/10.1614/WS-D-14-00071.1

Teodoro, R. B., Oliveira, F. L., Silva, D. M. N., Fávero, C., \& Quaresma, M. A. L. (2011). Aspectos agronômicos de leguminosas para adubação verde no cerrado do alto vale do Jequitinhonha. Revista Brasileira de Ciência do Solo, 35(2), 635-643. https://doi.org/10.1590/S0100-06832011000200032

Timossi, P. C., Wisintainer, C., Santos, B. J., Pereira, V. A., \& Porto, V. S. (2011). Supressão de plantas daninhas e produção de sementes de crotalária, em função de métodos de semeadura. Pesquisa Agropecuária Tropical, 41(4), 525-530. https://doi.org/10.5216/pat.v41i4.11603

Tivelli, S. W., Kano, C., Purqueiro, L. F. V., Wutke, E. B., \& Ishimura, I. (2013). Desempenho do quiabeiro consorciado com adubos verdes eretos de porte baixo em dois sistemas de cultivo. Horticultura Brasileira, 31(3), 483-488. 


\section{Macrothink}

Journal of Agricultural Studies

ISSN 2166-0379 2020, Vol. 8, No. 4

https://doi.org/10.1590/S0102-05362013000300023

Wutke, E. B., Calegari, A., \& Wildner, L. P. (2014). Espécies de adubos verdes e plantas de cobertura e recomendações para seu uso. In O. F. L. Filho, E. J. Ambrosano, F. Rossi, \& J. A. D. Carlos (Eds.), Adubação verde e plantas de cobertura no Brasil: fundamentos e prática (pp. 59-167). Brasília: Embrapa.

Zucchi, M. R., Perinnazzo, F. K., Peixoto, N., Mendanha, W. R., \& Zatarin, M. A. (2012). Associação das culturas de quiabo e feijão-caupi. Revista Agrotecnologia, 3(2), 12-23. https://doi.org/10.12971/2179-5959.v03n02a02

\section{Copyright Disclaimer}

Copyright for this article is retained by the author(s), with first publication rights granted to the journal.

This is an open-access article distributed under the terms and conditions of the Creative Commons Attribution license (http://creativecommons.org/licenses/by/4.0/). 